\title{
Marek Michalak, Order Uśmiechu - wspólny świat dzieci i dorosłych, Warszawa 2020
}

\author{
W moim domu i w sercu zagościł Janusz Korczak, którego dorosłemu często trudno zrozumieć, \\ gdyż próbuje to zrobić tylko przez symboliczne okulary świata dorosłych.
}

Marek Michalak

Na rynku wydawniczym pojawiają się książki z zakresu dydaktyki i pedagogiki dziecka, dzieciństwa oraz dorosłości; książki, które dają tylko teoretyczną wiedzę o dziecku i dorosłym, wiedzę, która zamyka się w sztywnej parametryzacji. Nie chcę tutaj wchodzić w dyskurs ich wartościowania, ale w pytania o sens i celowość. Albert Einstein, uczony i wirtuoz najwyższej klasy, uważał, że są dwa kryteria prawdziwości naukowej teorii - jej empiryczne potwierdzenie i jej wewnętrzne piękno. Empiria i piękno są symptomem prawdziwości.

I oto do rąk Czytelników trafiła książka Marka Michalaka Order Uśmiechu - wspólny świat dzieci i dorosłych, publikacja, której konceptualizacja zawarta jest w empirii historyczności Orderu Uśmiechu i możliwym pięknie w relacji wzajemnego obdarowywania się na płaszczyźnie dziecko dorosły.

Dziedzictwo Janusza Korczaka stanowiące jądro „instytucji”, jaką jest Order Uśmiechu, bez wątpienia stanowi źródło mądrości, które powinno rozpościerać się u podłoża nie tylko ładu społecznego, ubogacania tożsamości osobowościowej dziecka i dorosłego, ale jest doskonałym imperatywem dającym nowe impulsy dla "nowych czasów” w kategorii "nowego wychowania” czy też samowychowania. W pełni popieram słowa Barbary Smolińskiej-Theiss z przedmowy recenzowanej publikacji, że „książka dra Marka Michalaka mówi o dawaniu, o darach, obdarowywaniu. Tym razem na planie pierwszym staje pytanie nie o to, co dorośli dają lub powinni dać dzieciom, ale o to, czym dzieci obdarowują wyjątkowych, nadzwyczajnych dorosłych. Takim dziecięcym darem jest Order Uśmiechu - fenomen pedagogiczny, wyjątkowe działanie i oryginalna instytucja w skali polskiej i międzynarodowej. Order Uśmiechu sprawia, że dzieci i dorośli spotykają się we wspólnej korczakowskiej przestrzeni, we wspólnym świecie dzieciństwa wychylonego w stronę dorosłości i dorosłości, która nie zatraca wektora dzieciństwa. Jest to otwarta przestrzeń”.

Wczytawszy się w recenzowaną publikację, mogę stwierdzić, że mamy w każdej z jej siedmiu rozdziałów do czynienia z intelektualną uczciwością, precyzją naukową i doświadczeniem Autora Rzecznika Praw Dziecka dwóch kadencji (2008-2018), człowieka łączącego bycie ojcem, wychowawcą i nauczycielem akademickim, kanclerzem Międzynarodowej Kapituły Orderu Uśmiechu oraz kierującym międzynarodowym ruchem korczakowskim jako przewodniczący Międzynarodowego Stowarzyszenia im. Janusza Korczaka.

Książka napisana jest w duchu twórczej innowacyjności, nie tylko pozwala zdobyć nową wiedzę o relacji dziecko - dorosły w konstelacji Orderu Uśmiechu, ale dotychczasową uporządkować i scalić, by powstawały nowe dzieła naukowe i praktyczne inicjatywy ubogacające nie tylko świat nauki, ale zagospodarowujące praktyczną przestrzeń życia w harmonii jedności dziecka i dorosłego. Można stwierdzić, że racjonalność i mądrość publikacji nie tylko ocala od zapomnienia myśl Korczaka, 
dzieła Kawalerów Orderu Uśmiechu, ale pozwala ocalić od zagubienia się dzisiejszemu dorosłemu (rodzicowi, nauczycielowi) w coraz to bardziej złożonym świecie dziecka we współczesnej rzeczywistości.

Przez zawartość poszczególnych rozdziałów Czytelnik publikacji zrozumie, że ma do czynienia z integralnością empirii życia i naukową dociekliwością, które pokazują prawdę o relacji dziecko dorosły. Poszczególne rozdziały pozwalają Czytelnikowi na zgłębienie relacji i więzi w różnorakich odniesieniach - osobistych, zawodowych, społecznych, instytucjonalnych. Odczytując myśl Korczaka, Kawalerów Orderu Uśmiechu, ma się przeświadczenie, że właściwe relacje dziecko - dorosły, dorosły - dziecko nie mają asymetrii oddziaływań, ale symetryczność wzajemności. To co „stare” (historyczne) w czasie współczesnych, globalizacyjnych „przemian” nie musi być w zapomnieniu, ale może jawić się jako „nowe” w kategorii naukowo-praktycznego odczytania tej myśli. Ma to w analizowanej publikacji zasadnicze znaczenie, dzięki czemu przestrzeń relacyjności posiada swój dynamizm piękna i nie musi zanudzać, wymaga trudu, dając nowe impulsy do osobowościowo-społecznego doskonalenia się. Bez cienia wątpliwości stwierdzam, że każdy rozdział w recenzowanej publikacji zawiera swoją mądrość, a nie tylko kompilacyjną wiedzę. Mądrość ta jest gwarantem ładu i twórczej relacji dziecko - dorosły, a co za tym idzie, prowadzi do ładu społeczeństwa demokratycznego.

Publikacja opatrzona polami poznawczymi w precyzyjnym ujęciu ukazuje, jak droga, jaką jest relacja między światem dziecka a światem dorosłego, permanentnie domaga się ubogacania.

Książka łączy zalety interesującej poznawczo i poprawnej metodologicznie publikacji naukowej oraz nośnika o charakterze aplikacyjnym.

Order Uśmiechu - wspólny świat dzieci i dorosłych ma niewątpliwie walory teoriopoznawcze i wnosi cenny wkład do pedagogiki, socjologii, psychologii oraz innych nauk. Nie tylko obliguje Czytelnika do spojrzenia na powyższe kwestie okiem analitycznego teoretyka, ale również wskazuje pola aktualnych zastosowań i dalszych badań naukowych czy konferencji.

Książka napisana jest dobrym językiem, opiera się na solidnej wiedzy Autora. Szata graficzna, struktura, łącznie z indeksem osobowym, stanowi (wcale nie dodatkową) jej wartość. Powinna być zarekomendowana szerokim rzeszom Czytelników czy też instytucjom, którym w prawdzie czynu, a nie tylko poprzez „pustosłowie” zależy na dojrzałej i mądrej relacji dziecko - dorosły. Sięgnąć po nią powinni nie tylko nauczyciele akademiccy, szkół różnych szczebli i profili, lecz także rodzice i wychowawcy oraz osoby aktualnie odpowiedzialne w dykasteriach ministerialnych za edukację i wychowanie.

Pragnę przeto Panu dr. Markowi Michalakowi nie tylko pogratulować tegoż dzieła, ale życzyć dalszych tego rodzaju inwencji na rzecz mądrej edukacji i twórczego wychowania.

Adam Solak

DOI: $10.14746 / p s n .2021 .2 .12$ 